\title{
Cellulase hydrolyzed Indigofera zolingeriana leaf utilization as a feed ingredient for gourami fingerling
}

\section{Pemanfaatan daun Indigofera zolingeriana yang dihidrolisis enzim selulase sebagai bahan baku pada pakan benih ikan gurami}

\author{
Jefry $^{1}$, Mia Setiawati ${ }^{1}$, Dedi Jusadi ${ }^{1}$, Ichsan Achmad Fauzi ${ }^{1}$ \\ 'Department of Aquaculture Faculty of Fisheries and Marine Sciences, IPB University, \\ Bogor, West Java, Indonesia 16680 \\ *Corresponding author: miasetia@apps.ipb.ac.id
}

(Received September 17, 2018; Accepted October 24, 2018)

\begin{abstract}
This study was aimed to evaluate the utilization of hydrolyzed Indigofera zolingeriana by celullase enzyme as the feed ingredient of gourami fish. This study used a completely randomized design which contained three steps, whereas each step contained four treatments and four replications. The first step performed by evaluating the Indigofera leaf meal (ILM) added with cellulase enzyme of $0 \mathrm{~g} / \mathrm{kg}$ (control), $0.4 \mathrm{~g} / \mathrm{kg}, 0.8 \mathrm{~g} / \mathrm{kg}$, and $1.2 \mathrm{~g} / \mathrm{kg}$. The second step was the digestibility test of ILM on gourami seeds. The third step was feed evaluation added with ILM as much as $0 \%$ (control) $15 \%, 30 \%$, and $45 \%$ against the growth performance on gourami seeds. The gourami seeds used in the second and third steps with a weight of $13.65 \pm 0.39 \mathrm{~g} / \mathrm{seed}$ and $5.95 \pm 0.15 \mathrm{~g} / \mathrm{seed}$, respectively. The addition of $0.8 \mathrm{~g} / \mathrm{kg}$ and $1.2 \mathrm{~g} / \mathrm{kg}$ cellulase enzyme could significantly decrease the crude fiber of ILM with $43.33 \%$, besides having the best value of total, ingredient, protein, lipid, and energy digestibility. The growth performance of gourami seeds given 15\% ILM added feed had the best value and insignificantly different from the control feed without ILM addition based on the specific growth rate (SGR), protein retention (PR), and feed efficiency (FE).
\end{abstract}

Keywords: Cellulase, feed, hydrolyze, Indigofera zolingeriana, Osphronemus gouramy.

\begin{abstract}
ABSTRAK
Penelitian ini dilakukan untuk mengevaluasi pemanfaatan daun Indigofera zolingeriana yang dihidrolisis enzim selulase sebagai bahan baku pada pakan benih ikan gurami. Penelitian ini menggunakan rancangan acak lengkap yang terdiri atas tiga tahap dan masing-masing tahap terdiri dari empat perlakuan dan empat ulangan. Pada tahap pertama dilakukan evaluasi tepung daun Indigofera (TDI) yang ditambahkan enzim selulase sebesar $0 \mathrm{~g} / \mathrm{kg}$ (kontrol), $0.4 \mathrm{~g} / \mathrm{kg}, 0.8 \mathrm{~g} / \mathrm{kg}$, dan $1.2 \mathrm{~g} / \mathrm{kg}$. Pada tahap kedua dilakukan uji kecernaan bahan TDI pada benih ikan gurami. Pada tahap ketiga dilakukan evaluasi pakan yang ditambahkan TDI sebesar 0\% (kontrol), 15\%, 30\% dan 45\% terhadap kinerja pertumbuhan pada benih ikan gurami. Benih ikan gurami yang digunakan pada penilitian tahap kedua dengan bobot $13.65 \pm 0.39 \mathrm{~g} /$ ekor dan $5.95 \pm 0.15 \mathrm{~g} / \mathrm{ekor}$. Penambahan enzim selulase pada dosis 0.8 $\mathrm{g} / \mathrm{kg}$ dan $1.2 \mathrm{~g} / \mathrm{kg}$ secara signifikan mampu menurunkan serat kasar TDI sebesar $43.33 \%$ dan memberikan nilai terbaik terhadap nilai kecernaan total, kecernaan bahan, kecernaan protein, kecernaan lemak dan kecernaan energi. Kinerja pertumbuhan benih ikan gurami yang diberikan pakan yang ditambahkan TDI sebesar 15\% memilki nilai terbaik dan tidak berbeda nyata terhadap pakan kontrol tanpa TDI dari aspek laju pertumbuhan spesifik (LPS), retensi protein $(\mathrm{RP})$ dan efisiensi pakan $(\mathrm{EP})$.
\end{abstract}

Kata kunci: Hidrolisis, Indigofera zolingeriana, Osphronemus gouramy, pakan, selulase. 


\section{INTRODUCTION}

Feed is one of the important aspects on intensive fish culture. The most important component in fish feed is protein content. Common plant protein source utilized in feed is soybean meal and fish meal. According to BPS (2019), Indonesian soybean meal import inclined from 1.7 million tons in 2010 to 2.6 million tons in 2019. Fish meal play a huge role in fish diet industry because it holds such a large amount of nutrition (Rahman et al., 2016). In contrast, the cost of using fish meal as the main ingredient of fish diet is relatively high. Therefore, alternative ingredient is required with cheaper price and higher quality. One of the ingredients utilized as plant protein source is Indigofera leaf. Indigofera plant is a leguminose plant that mostly found in Indonesia and grows fastly and adaptively against low soil fertility (Abdullah, 2014; Fugarasti et al., 2020). According to Herdiawan and Krisnan (2014), Indigofera plant spreads mostly in Java, Sumatera, Sumba, and Flores Island with 52 ton/ ha/year production capacity.

Indigofera zollingeriana is a plant containing approximately $29.06 \%$ of protein source (Pangentasari, 2018). Kumalasari et al. (2017) also stated that Indigofera zollingeriana contained 25.17\%-26.44\%. According to Palupi et al. (2014), the amino acid contents in Indigofera leaf are histidine $0.67 \%$, threonine $1.14 \%$, arginine $1.67 \%$, tyrosine $1.05 \%$, methionine $0.43 \%$, valine $1.56 \%$, phenylalanine $1.60 \%$, isoleucine $1.35 \%$, leucine $2.26 \%$, and lysine $1.57 \%$. The study also reported that the crude fiber in Indigofera leaf ranged from $27.68 \%$ or $28.98 \%$. However, it has a limiting factor to be utilized as a protein ingredient source in fish feed due to high crude fiber. Sun $e t$ al. (2019) also confirmed that crude fiber is hardly digested and absorbed by fish. According to SNI 7473:2009, the tolerable crude fiber content in fish feed is around 5-8\%. It inevitably limits the utilization for feed (Caruso, 2015; Daniel, 2018) because it will lead to low digestibily (Pandey, 2013). According to Melati and Sunarno (2016), crude fiber contains ADF (acid detergent fiber), NDF (neutral detergent fiber), cellulose, hemicelluloses, and lignin fraction. One attempt that can be done to reduce the crude fiber content and anti-nutrient compounds is by using hydrolysis enzyme (Olude et al., 2016).

Hydrolysis is commonly known as cellulose breakdown process (Ketut et al., 2017).
Hydrolysis enzyme can eliminate the excess crude fiber content and anti-nutrient compounds (tannins and phytic acid) on bran, wheat, rice plants, and seeds (Dhingra et al., 2012; Raveendran et al., 2018). This particular process is possible to improve the nutritive value of each feed ingredients (Bae et al., 2019). This condition is also expected to have similar effect in I. zollingeriana leaf meal. Therefore, it can conceivably maintain the digestibility level (Zuraida et al., 2012; Pamungkas, 2012). One of hydrolysis enzyme types can be found in cellulase enzyme. The commercial product of cellulase enzyme contains $20000 \mathrm{U} / \mathrm{g}$ enzyme activity. According to Nurliana et al. (2019), crude fiber content in feed ingredient can be declined using cellulase enzyme by hydrolyzing the cellulose macromolecules, then transformed into easily digested simple molecules.

As the I. zollingeriana leaf meal can be used as an alternative feed ingredient after being hydrolyzed with commercial cellulase enzyme product, this feed ingredient should be tested its digestibility and effect on the fish growth. The fish growth test can be performed in herbivore fish such as gourami, Osphronemus gouramy. This particular species is one of the most excellent freshwater fish commodities with high economical value and relatively stabilized cost. Based on DJPB (2017), the production of gourami in 2017 reached 149552.70 tons, increased from 118776.39 tons in 2014. However, the protein content in gourami feed is still low, specifically the plant protein content, as good protein level for gourami feed is 30\% (Mithun et al., 2018). This study was aimed to evaluate the utilization of cellulase hydrolyzed I. zollingeriana as plant protein source feed ingredient on gourami fingerling. Thus, further studies are necessary to determine the proper content of plant protein source using I. zollingeriana leaf meal in gourami feed.

\section{MATERIALS AND METHODS}

\section{Period and location}

This study was performed on October 2019 until March 2020 in the Laboratory of Fish Nutrition, Department of Aquaculture, Faculty of Fisheries and Marine Sciences, IPB University, Bogor. Feed preparation and production activity were performed in the laboratory of feed processing. Proximate analysis was performed 
in the chemical laboratory of fish nutrition. The tested fish was reared in the laboratory of fish nutrition, Department of Aquaculture, Faculty of Fisheries and Marine Sciences, IPB University, Bogor.

\section{Experimental design}

First step: Indigofera leaf hydrolysis

The first step was a hydrolysis process of $I$. zollingeriana meal using a completely randomized experimental design containing four treatments and four replications. Hydrolysis process was started from preparing the indigofera leaf meal ingredient (ILM) and cellulase enzyme as well as proximate analysis of ILM ingredient before and after hydrolysis. The ingredients were milled, grinded, and mixed with cellulase enzyme based on each treatment as much as $0.4,0.8$, and $1.2 \mathrm{~g} /$ $\mathrm{kg}$. After that, the mixture was dissolved in water as many of $30 \%$ of the ingredient, then thoroughly mixed. The hydrolysis process was performed in a plastic container at room temperature for 24 hours. Thereafter the hydrolyzed ILM ingredient was dried using an oven at $60^{\circ} \mathrm{C}$ for 1.5 hours. The indigofera leaf meal hydrolysis test is presented below:

$\begin{array}{ll}\text { ILM } & \begin{array}{l}\text { : Indigofera leaf meal without } \\ \text { cellulase enzyme } \\ \text { : Indigofera leaf meal }+0.4 \mathrm{~g} / \mathrm{kg} \\ \text { cellulase enzyme }\end{array} \\ 0.4 \mathrm{ILM} & \begin{array}{l}: \text { Indigofera leaf meal }+0.8 \mathrm{~g} / \mathrm{kg} \\ \text { cellulase enzyme }\end{array}\end{array}$

\subsection{ILM : Indigofera leaf meal $+1.2 \mathrm{~g} / \mathrm{kg}$ cellulase enzyme}

\section{Parameters}

Ingredient chemical analysis performed in this study step were NDF (neutral detergent fiber) and ADF (acid detergent fiber) analysis using In Sacco method (Van Soest, 1976), as well as hydrolyzed and non-hydrolyzed ILM proximate analysis. The proximate analysis contained crude protein, moisture, crude lipid, crude fiber, and ash. Crude protein analysis used Kjeldahl method, moisture and ash content were performed using Gravimetric method and crude lipid used Soxhlet method (AOAC, 1995).

\section{Second step: hydrolyzed Indigofera ingredient digestibility test}

Ingredient digestibility test was performed using a completely randomized design containing four treatments and four replications. Ingredient test used was commercial feed, non-hydrolyzed ILM, hydrolyzed ILM on certain dozes, and $0.3 \%$ $\mathrm{Cr} 2 \mathrm{O} 3$ as digestibility test indicator. The tested fish was fed using commercial feed with $32 \%$ of protein content. The tested fish used with the total average length $7.75 \pm 0.18 \mathrm{~cm}$ of and weight of $13.65 \pm 0.39 \mathrm{~g}$ were obtained from gourami fish hatchery in Ciseeng, Bogor. The stocking density used was 12 fish/90/L and fed with satiation method three times a day at satiation. The feed formulation for ingredient digestibility test is presented in Table 1.

Table 1. Feed formulation for ingredient digestibility test on gourami fingerlings

\begin{tabular}{lccccc}
\hline \multirow{2}{*}{ Ingredient } & \multirow{2}{*}{ Reference diet $(\%)$} & \multicolumn{5}{c}{ Feed treatment } \\
\cline { 3 - 6 } & & $0 \mathrm{~g} / \mathrm{kg}$ & $0.4 \mathrm{~g} / \mathrm{kg}$ & $0.8 \mathrm{~g} / \mathrm{kg}$ & $1.2 \mathrm{~g} / \mathrm{kg}$ \\
\hline Commercial feed & 99.1 & 69.1 & 69.1 & 69.1 & 69.1 \\
$\mathrm{ILM}$ & & 30 & 30 & 30 & 30 \\
$\mathrm{Cr}_{2} \mathrm{O}_{3}$ & 0.6 & 0.6 & 0.6 & 0.6 & 0.6 \\
$\mathrm{CMC}$ & 0.3 & 0.3 & 0.3 & 0.3 & 0.3 \\
Total & 100 & 100 & 100 & 100 & 100 \\
\hline & \multicolumn{5}{c}{ Proximate analysis (dry base \%) } \\
\hline Protein & 31.36 & 30.12 & 30.23 & 30.79 & 30.51 \\
Lipid & 6.73 & 6.31 & 6.08 & 6.20 & 6.24 \\
Crude fiber & 3.93 & 5.88 & 5.66 & 5.53 & 5.16 \\
Ash & 11.73 & 11.84 & 11.67 & 11.6 & 11.18 \\
NFE & 46.25 & 45.85 & 46.36 & 45.87 & 46.91 \\
GE (Kcal/100 g) & 450.50 & 438.19 & 439.08 & 440.74 & 444.74 \\
\hline
\end{tabular}

Note: ILM = Indigofera leaf meal; $\mathrm{CMC}=$ Carboximethyl cellulase; NFE $=$ Nitrogen free extract; $\mathrm{GE}=$ Gross energy 


\section{Parameters}

Parameters determined on digestibility test contained of total digestibility using the method of Takeuchi (1988), total digestibility, nutrient digestibility (protein, lipid, and energy), and ingredient digestibility based on Watanabe (1988) method.

Third step: growth performance test of gourami fingerling

The third step was growth performance test on gourami fingerlings containing four treatments and four replications. Treatments from this study was the total ILM hydrolysis added in feed formulation as a replacement of soybean meal, namely $0 \%, 15 \%, 30 \%$, and $45 \%$. The test fish used had $5.88 \pm 0.15 \mathrm{~cm}$ length and 5.95 $\pm 0.15 \mathrm{~g}$ weight. The stocking density used was 15 fish/90 L water and fed three times a day at satiation. Feed production was performed by mixing all measured ingredients based on the formulation (Table 2), then stirred and pelleted using a pelleting machine. Pelleted feed was then dried in an oven at $60^{\circ} \mathrm{C}$ for 2 hours and moved into a plastic container. Feed formulation used for growth performance test can be seen in Table 2 .

\section{Parameters}

Growth performance test parameters determined contained: feed intake (FI), survival rate (SR), specific growth rate (SGR), protein efficiency ratio (PER), protein retention (PR), and enzyme activity (protease, amylase, and lipase).

\section{RESULTS AND DISCUSSION}

\section{Results}

The first study step presented that Indigofera leaf meal (ILM) with different cellulase enzyme dozes for 24 hours was significantly different $(\mathrm{P}<0.05)$ against declined crude fiber. The $1.2 \mathrm{~g} /$ $\mathrm{kg}$ cellulose enzyme doze had the most declined crude fiber, NDF, and hemicellulose on ILM hydrolysis process. The proximate analysis result on ILM ingredient can be seen in Table 3.

Table 2. Feed composition used for gourami fish fingerling using I. zollingeriana leaf meal hydrolysis.

\begin{tabular}{lcccc}
\hline \multirow{2}{*}{ Ingredient } & \multicolumn{4}{c}{ Ingredients ILM hydrolyzed in feed } \\
\cline { 2 - 5 } & $0 \%$ & $15 \%$ & $30 \%$ & $45 \%$ \\
\hline Fish meal & 10.00 & 10.00 & 10.00 & 10.00 \\
Meat bone meal (MBM) & 16.00 & 16.00 & 16.00 & 16.00 \\
Soybean meal & 31.00 & 23.00 & 16.00 & 8.00 \\
Hydrolyzed ILM & 0.00 & 15.00 & 30.00 & 45.00 \\
Pollard & 29.00 & 22.00 & 15.00 & 7.00 \\
Tapioca & 7.67 & 7.67 & 7.67 & 7.67 \\
Fish oil & 1.50 & 1.50 & 1.50 & 1.50 \\
Corn oil & 1.50 & 1.50 & 1.50 & 1.50 \\
Vitamin dan mineral mix & 3.00 & 3.00 & 3.00 & 3.00 \\
Phytase & 0,03 & 0,03 & 0,03 & 0,03 \\
CMC & 0,30 & 0,30 & 0,30 & 0,30 \\
\hline Total & 100.00 & 100.00 & 100.00 & 100.00 \\
\hline Proximate analysis (\%) & & & & \\
\hline Protein & 32.63 & 32.42 & 32.56 & 32,34 \\
Lipid & 7.30 & 7.61 & 7.94 & 8.21 \\
Crude fiber & 4.24 & 4.73 & 5.15 & 5.64 \\
Ash & 11.54 & 12.03 & 12.54 & 13.03 \\
NFE & 40.96 & 39.88 & 38.52 & 37.45 \\
GE (kcal/100 g) & 422.47 & 419.78 & 421.65 & 415.06 \\
C/P ratio & 12.91 & 12.91 & 12.79 & 12.79 \\
\hline Nerll
\end{tabular}

Note: ILM= Indigofera leaf meal; $\mathrm{CMC}=$ Carboximethyl cellulase; $\mathrm{NFE}=$ Nitrogen free extract; $\mathrm{GE}=$ Gross energy; $\mathrm{C} / \mathrm{P}$ Ratio= Caloric part protein ratio 
The most declined crude fiber value was resulted in the $1.2 \mathrm{~g} / \mathrm{kg}$ cellulase enzyme doze, followed by The declined neutral detergent fiber and hemicellulose value at $16.49 \%$ in the same enzyme doze. Meanwhile, the acid detergent fiber (ADF) value on $0.8 \mathrm{~g} / \mathrm{kg}$ and $1.2 \mathrm{~g} / \mathrm{kg}$ doze decreased significantly $(\mathrm{P}<0.05)$. The second study step results (Table 4) showed that the total, ingredient, protein, lipid, and energy digestibility on $0.8 \mathrm{~g} / \mathrm{kg}$ and $1.2 \mathrm{~g} / \mathrm{kg}$ doze had the best values to incline digestibility in gourami fingerlings.

The production performance of gourami fingerlings on third study step result was significantly different $(\mathrm{P}<0.05)$ among treatments (Table 5). The utilization of cellulase enzyme hydrolyzed ILM on feed formulation more than $15 \%$ (30\% and $45 \%$ ) had protein efficiency ratio (PER), protein retention (PR), specific growth rate (SGR), and protease enzyme activity value lower than control treatment with $100 \%$ plant protein source of soybean meal $(\mathrm{P}<0.05$, Table 5$)$.

Protease enzyme activity on control treatment and $15 \%$ doze also showed a higher result than $30 \%$ and $45 \%$ doze $(\mathrm{P}<0.05$; Table 5$)$. Increased ILM addition in feed (30\% and 45\%) made the protease enzyme tended to decrease.

\section{Discussion}

The most declined crude fiber value was resulted in the $1.2 \mathrm{~g} / \mathrm{kg}$ cellulase enzyme doze. Reasonably, it was caused by the cellulase enzyme that hydrolyze the complex components, such as cellulose and hemicellulose, into simply digestible glucoses. Cellulase enzyme is composed of endo$\beta$-1.4-gluconase, exo- $\beta$-1.4-gluconase, and $\beta-1.4-$ glucosidase enzyme (Crueger \& Crueger, 1984). Endo-1.4- $\beta$-D-glucanase enzyme has a function to degrade cellulose polymer randomly on internal bond of $\alpha-1.4$-glycosides into oligodextrines with various chain lengths, as well as exo- $\beta-1.4-$ gluconase and $\beta$-1.4-glucosidase enzyme that degrade cellulose from the reductor and nonreductor to produce cellobiose or glucose (Co et al., 2021).

Acid detergent fiber (ADF) value on $0.8 \mathrm{~g} /$ $\mathrm{kg}$ and $1.2 \mathrm{~g} / \mathrm{kg}$ doze decreased significantly $(\mathrm{P}<0.05)$. This condition was caused by the cellulose degradation process (ADF process), so that the higher cellulose was degraded by cellulase enzyme, the ADF value would be more declined (Kumar et al., 2019). The same result was also shown by Melati and Sunarno (2016), as the ADF value on cassava skin added with

Table 3. Proximate analysis of cellulase hydrolyzed I. zolingeriana.

\begin{tabular}{lcccc}
\hline \multirow{2}{*}{ Proximate analysis } & \multicolumn{4}{c}{ Cellulase enzyme doze } \\
\cline { 2 - 5 } & $0 \mathrm{~g} / \mathrm{kg}$ & $0.4 \mathrm{~g} / \mathrm{kg}$ & $0.8 \mathrm{~g} / \mathrm{kg}$ & $1.2 \mathrm{~g} / \mathrm{kg}$ \\
\hline Protein (\%) & $30.35 \pm 0.38^{\mathrm{a}}$ & $30.91 \pm 1.97^{\mathrm{a}}$ & $31.12 \pm 0.19^{\mathrm{a}}$ & $30.25 \pm 1.60^{\mathrm{a}}$ \\
Lipid (\%) & $4.57 \pm 0.50^{\mathrm{a}}$ & $4.79 \pm 0.43^{\mathrm{a}}$ & $4.84 \pm 0.30^{\mathrm{a}}$ & $5.04 \pm 0.40^{\mathrm{a}}$ \\
Ash (\%) & $9.12 \pm 0.15^{\mathrm{a}}$ & $9.28 \pm 0.26^{\mathrm{a}}$ & $9.19 \pm 0.08^{\mathrm{a}}$ & $9.21 \pm 0.35^{\mathrm{a}}$ \\
Crude fiber (\%) & $17.03 \pm 0.11^{\mathrm{d}}$ & $15.30 \pm 0.50^{\mathrm{c}}$ & $10.90 \pm 0.37^{\mathrm{b}}$ & $9.65 \pm 0.32^{\mathrm{a}}$ \\
NFE (\%) & $38.93 \pm 0.75^{\mathrm{b}}$ & $39.72 \pm 1.64^{\mathrm{b}}$ & $43.95 \pm 0.59^{\mathrm{a}}$ & $45.85 \pm 2.21^{\mathrm{a}}$ \\
NDF (\%) & $36.38 \pm 0.10^{\mathrm{d}}$ & $33.57 \pm 0.14^{\mathrm{c}}$ & $31.67 \pm 0.14^{\mathrm{b}}$ & $30.38 \pm 0.34^{\mathrm{a}}$ \\
ADF (\%) & $26.19 \pm 0.18^{\mathrm{c}}$ & $25.47 \pm 0.09^{\mathrm{b}}$ & $24.93 \pm 0.11^{\mathrm{a}}$ & $24.88 \pm 0.11^{\mathrm{a}}$ \\
Hemicellulose (\%) & $10.19 \pm 0.25^{\mathrm{d}}$ & $8.11 \pm 0.14^{\mathrm{c}}$ & $6.74 \pm 0.12^{\mathrm{b}}$ & $5.50 \pm 0.32^{\mathrm{a}}$ \\
\hline
\end{tabular}

Note: $\mathrm{NFE}=$ Nitrogen free extract; $\mathrm{NDF}=$ Neutral detergent fiber; $\mathrm{ADF}=$ Acid detergent fiber

Table 4. Total, ingredient, protein, lipid, and energy digestibility of Indigofera leaf meal on gourami fingerling feed

\begin{tabular}{lcccc}
\hline \multirow{2}{*}{\multicolumn{1}{c}{ Parameter $(\%)$}} & $0 \mathrm{~g} / \mathrm{kg}$ & $0.4 \mathrm{~g} / \mathrm{kg}$ & $0.8 \mathrm{~g} / \mathrm{kg}$ & $1.2 \mathrm{~g} / \mathrm{kg}$ \\
\cline { 2 - 5 } & $71.64 \pm 0.81^{\mathrm{b}}$ & $72.15 \pm 0.50^{\mathrm{b}}$ & $73.50 \pm 0.33^{\mathrm{a}}$ & $73.82 \pm 0.75^{\mathrm{a}}$ \\
\hline Total digestibility & $61.75 \pm 2.61^{\mathrm{b}}$ & $65.57 \pm 1.60^{\mathrm{b}}$ & $69.02 \pm 1.08^{\mathrm{a}}$ & $70.82 \pm 2.44^{\mathrm{a}}$ \\
Ingredient digestibility & $85.58 \pm 0.67^{\mathrm{b}}$ & $86.04 \pm 0.42^{\mathrm{b}}$ & $87.24 \pm 0.61^{\mathrm{a}}$ & $87.26 \pm 0.46^{\mathrm{a}}$ \\
Protein digestibility & $76.25 \pm 0.78^{\mathrm{b}}$ & $76.37 \pm 1.21^{\mathrm{b}}$ & $78.31 \pm 0.61^{\mathrm{a}}$ & $78.87 \pm 0.95^{\mathrm{a}}$ \\
Lipid digestibility & $78.91 \pm 0.50^{\mathrm{b}}$ & $78.90 \pm 0.52^{\mathrm{b}}$ & $79.89 \pm 0.27^{\mathrm{a}}$ & $80.24 \pm 0.53^{\mathrm{a}}$ \\
\hline Energy digestibility & &
\end{tabular}

Note: Different letters on the same line show a significant difference $(\mathrm{P}<0.05)$. Values are presented in average \pm standard deviation. 
cellulase enzyme could decline until $1.65 \%$. The neutral detergent fiber and hemicellulose value on $1.2 \mathrm{~g} / \mathrm{kg}$ doze declined significantly until $16.49 \%$. Significantly, declined NDF value was suspected due to the reaction between cellulase enzyme and hemicellulose contained in ILM. According to Jamarun et al. (2017), NDF is composed of ADF and hemicellulose which has smaller molecules than cellulose, therefore easily degraded by cellulase enzyme.

The second study step results (Table 4) showed that the total, ingredient, protein, lipid, and energy digestibility on $0.8 \mathrm{~g} / \mathrm{kg}$ and $1.2 \mathrm{~g} / \mathrm{kg}$ doze had the best values to incline digestibility in gourami fingerlings. This condition was caused as crude fiber content on feed ingredient declined, therefore inclining the digestibility value of gourami fingerlings. The digestibility of the feed is determined by various factors, e.g. feed chemical composition and feed preparation (Mayulu, 2014). Supporting Mayulu (2014), Suprayudi et al. (2011), digestibility value is influenced by some factors as one of which are crude fiber content. The higher crude fiber value, the lower feed digestibility value. Digestibility value has a positive correlation against fish growth. The higher digestibility value of fish, the better feed digested by fish as energy source and growth (Bokau et al., 2018; Hassaan et al., 2019; Azaza et al., 2020). Based on the results (Table 4 ), the digestibility value on each ILM treatment in a commonly normal fish range is $75-95 \%$ for protein digestibility and 70-85\% for energy digestibility (NRC, 1993). Vinasyiam et al. (2016) identified tilapia treated with rElGH performed a higher protein digestion, and retention in the body. It contributed in a lower ammonia excretion rate that enhanced growth of the fish.

The production performance of gourami fingerlings on third study step result was significantly different $(\mathrm{P}<0.05)$ among treatments (Table 5). The utilization of cellulase enzyme hydrolyzed ILM on feed formulation more than $15 \%$ (30\% and $45 \%$ ) had protein efficiency ratio (PER), protein retention (PR), specific growth rate (SGR), and protease enzyme activity value lower than control treatment with $100 \%$ plant protein source of soybean meal $(\mathrm{P}<0.05$, Table 5$)$. Mukti et al. (2019) stated that the best growth rate was recorded in $20 \%$ of ILM. In contrast, higher content of ILM (30\%) tended to reduce the growth rate. Antinutritional compound was suspected to decrease the growth rate (Samtiya et al., 2020). Phytic acid and trypsin inhibitor, common antinutritional compounds, can adversely affect the feed taste, intake, and nutrient absorption, resulting in a diminishing in fish growth (Burr et al., 2012; Haghbayan \& Mehrgan, 2015). Higher concentration of tannin and saponin in the higher ILM content presumably diminished the digestibility and nutrient absorbtion. This condition was also suspected due to ILM amino acid content in the form of arginine had 1.67\% lower than soybean meal with $3.48 \%$, therefore suspected to cause amino acid deficiency that impacted the gourami fish fingerling growth. However, the production performance value on $15 \%$ ILM feed doze was similar to control feed $(\mathrm{P}<0.05)$. This indicates that the utilization of $15 \%$ ILM can be utilized well by fish, therefore

Table 5. Production performance of gourami fingerlings on growth test added with ILM on a certain doze in feed.

\begin{tabular}{lcccc}
\hline \multirow{2}{*}{ Parameter } & \multicolumn{4}{c}{ ILM hydrolysis utilization in feed } \\
\cline { 2 - 5 } & $0 \%$ & $15 \%$ & $30 \%$ & $45 \%$ \\
\hline FI (g/fish) & $46.68 \pm 2.44^{\mathrm{a}}$ & $47.49 \pm 0.94^{\mathrm{a}}$ & $44.44 \pm 0.59^{\mathrm{b}}$ & $44.44 \pm 1.46^{\mathrm{b}}$ \\
PER & $2.03 \pm 0.07^{\mathrm{a}}$ & $2.03 \pm 0.05^{\mathrm{a}}$ & $1.63 \pm 0.05^{\mathrm{b}}$ & $1.41 \pm 0.07^{\mathrm{c}}$ \\
PR (\%) & $38.16 \pm 0.96^{\mathrm{a}}$ & $38.04 \pm 1.10^{\mathrm{a}}$ & $29.50 \pm 0.98^{\mathrm{b}}$ & $24.50 \pm 1.54^{\mathrm{c}}$ \\
SGR (\%) & $3.05 \pm 0.10^{\mathrm{a}}$ & $3.10 \pm 0.07^{\mathrm{a}}$ & $2.73 \pm 0.08^{\mathrm{b}}$ & $2.53 \pm 0.11^{\mathrm{c}}$ \\
HSI & $1.70 \pm 0.11^{\mathrm{a}}$ & $1.70 \pm 0.01^{\mathrm{a}}$ & $1.77 \pm 0.08^{\mathrm{a}}$ & $1.73 \pm 0.09^{\mathrm{a}}$ \\
FE & $66.25 \pm 2.16^{\mathrm{a}}$ & $65.51 \pm 1.60^{\mathrm{a}}$ & $53.31 \pm 1.49^{\mathrm{b}}$ & $45.58 \pm 2.24^{\mathrm{c}}$ \\
\hline SR (\%) & 100 & 100 & 100 & 100 \\
Protease (unit/mL/min.) & $0.0990 \pm 0.0078^{\mathrm{a}}$ & $0.0917 \pm 0.0030^{\mathrm{a}}$ & $0.0727 \pm 0.0126^{\mathrm{b}}$ & $0.0682 \pm 0.0070^{\mathrm{b}}$ \\
Lipase (unit/mL/min.) & $0.0105 \pm 0.0014^{\mathrm{a}}$ & $0.0100 \pm 0.0017^{\mathrm{a}}$ & $0.0105 \pm 0.0014^{\mathrm{a}}$ & $0.0100 \pm 0.0017^{\mathrm{a}}$ \\
Amylase (unit/mL/min.) & $0.4427 \pm 0.0294^{\mathrm{c}}$ & $0.4874 \pm 0.0238^{\mathrm{b}}$ & $0.5233 \pm 0.0158^{\mathrm{a}}$ & $0.5508 \pm 0.0024^{\mathrm{a}}$ \\
\hline No: FI= Feed intake; PER
\end{tabular}

Note: FI= Feed intake; PER= Protein efficiency ratio; PR= Protein retention; SGR= Spesific growth rate; HSI= Hepatosomatic index; $\mathrm{FE}=$ Feed efficiency; $\mathrm{SR}=$ Survival rate 
feed nutrient can be preserved efficiently for fish growth performance.

Protease enzyme activity on control treatment and $15 \%$ doze also showed a higher result than $30 \%$ and $45 \%$ doze $(\mathrm{P}<0.05$; Table 5$)$. According to Santos et al. (2020), declined protease enzyme activity is caused by some factors, such as protein ingredient source and high value of glucose/ monosaccharides in feed. Therefore, the amino acid transport in digestive tract is inhibited due to this condition. Increased ILM addition in feed (30\% and $45 \%$ ) made the protease enzyme tended to decrease. This was suspected because glucose content on $30 \%$ and $45 \%$ ILM feed doze increased. A similar result was found in $\mathrm{Li}$ et al. (2020) as $16 \%$ glucose diet decreased the protease enzyme activity in Rhynchocypris lagowskii Dybowski.

\section{CONCLUSION}

The utilization of hydrolyzed I. zollingeriana leaf meal by cellulase enzyme with $1.2 \mathrm{~g} / \mathrm{kg}$ doze as much as $15 \%$ in feed composition can produce an optimum gourami fingerling growth performance.

\section{REFERENCES}

Abdullah L. 2014. Prospektif agronomi dan ekofisiologi Indigofera zollingeriana sebagai tanaman penghasil hijauan pakan berkualitas tinggi. Pasutra 3: 79-83.

[AOAC] Association of Official Analytical Chemists. 1995. Official Method of Analysis of The Association of Official Analytical Chemist. Arlington. Virginia. USA : Association of Official Analytical Chemists. Inc.

Azaza MS, Saidi SA, Dhraief MN, EL-feki A. 2020. Growth performance, nutrient digestibility, hematological parameters, and hepatic oxidative stress response in juvenile Nile Tilapia, Oreochromis niloticus, fed carbohydrates of different complexities. Animals 10: 1913.

Bae JH, Azad AK, Won SH, Hamidoghli A, Seong MJ, Bai SC. 2019. Effects of enzymatically hydrolyzed fish by products in diet of juvenile rainbow trout Oncorhynchus mykiss. Fisheries and Aquatic Sciences 22: 1.

Bokau RJM, Febriani D, Indariyanti N, Rakhmawati. 2018. Dosage optimization of artificial digestive enzymes in feed to improve the digestibility and growth of Osphronemus gourami. Aquacultura Indonesiana 19: 83-89.
[BPS] Badan Pusat Statistik. 2019. [internet]. [diunduh tanggal 01 Oktober 2020]; terdapat pada: Ekspor-Impor. https ://www.bps.go.id/ Subjek/view/id/8.

[BSN] Badan Standardisasi Nasional 2009. Pakan Buatan Untuk Ikan Gurame. SNI 7473:2009. Badan Standardisasi Nasional (ID). Jakarta

Burr GS, William RW, Frederic TB, Ronald WH. 2012. Replacing fish meal with blends of alternative proteins on growth performance of rainbow trout Oncorhynchus mykiss, and early or late stage juvenile Atlantic salmon Salmo salar. Aquaculture 334: 110-116.

Caruso G. 2015. Use of plant products as candidate fish meal substitute: An emerging issue in aquaculture productions. Fisheries and Aquaculture Journal 6: 1-3.

Co R, Hug LA. 2021. A need for improved cellulase identification from metagenomic sequence data. Applied and Environmental Microbiology 87: e01928-20.

Crueger W, Crueger A. 1984. Biotechnology A Text Book of Industrial Microbiology. Translated by Caroline Haessly. Science Tech. Madison

Daniel N. 2018. A review on replacing fish meal in aqua feeds using plant protein sources. International Journal of Fisheries and Aquatic Studies 6: 164-179.

Dhingra D, Michael M, Rajput H, Patil RT. 2012. Dietary fibre in foods: a review. Journal of Food Science Technology 49: 255-266.

[DJPB] Direktorat Jendral Perikanan Budidaya. 2017. Statistik Perikanan Budidaya Indonesia. Jakarta (ID): Kementerian Kelautan dan Perikanan.

Fugarasti H, Muzzazinah, Murni Ramli. 2020. Morphoanatomy of three Indigofera species (Leguminosae Papilionoideae) in Java, Indonesia. Biodiversitas 21: 5531-5539.

Haghbayan S, Mehrgan MS. 2015. The Effect of Replacing Fish Meal in the Diet with EnzymeTreated Soybean Meal (HP310) on Growth and Body Composition of Rainbow Trout Fry. Molecules 20: 21058-21066.

Hassaan MS, Mohammady EY, Soaudy MR, Abdel Rahman AAS. 2019. Exogenous xylanase improves growth, protein digestibility and digestive enzymes activities in Nile tilapia, Oreochromis niloticus, fed different ratios of fish meal to sunflower meal. Aquaculture Nutrition 25: 841-853.

Herdiawan I. Krisnan R. 2014. Productivity and utilization of leguminous tree Indigofera 
zollingeriana on dry land. WARTAZOA 24: $75-82$.

Jamarun N, Zain M, Arief, Pazla R. 2017. Effects of Calcium, Phosphorus and Manganese Supplementation During Oil Palm Frond Fermentation by Phanerochaete chrysosporium on Laccase Activity and in vitro DigestibilitY. Pakistan Journal of Nutrition 16: 119-124.

Ketut SN, Nico Y, Tika L, Dira E. 2017. Hydrolysis of cellulose from bamboo with biology process using enzyme. Advanced Science Letters 23: 12235-12238.

Kumalasari NR, Wicaksono GP, Abdullah L. 2017. Plant growth pattern, forage yield, and quality of Indigofera zollingeriana influenced by row spacing. Media Peternakan 40: 14-19.

Kumar A, Kurup RSC, Snishamol C, Prabhu GN. 2019. Role of Cellulases in food, feed, beverage, industries: Enzymes in industrial food processing. Green Bio-processes: 323343.

Li M, Kong YD, Li L, Zhu R, Wu LF. 2020. Effects of dietary carbohydrate sources on growth performance, immunity, and glycometabolic enzyme activity of Rhynchocypris lagowskii Dybowski. Aquaculture Research 52: 323333.

Mayulu H. 2014. The nutrient digestibility of locally sheep fed with amofer palm oil byproduct-based complete feed. International Journal of Science and Engineering 7: 106111.

Melati I. Sunarno MTD. 2016. Pengaruh enzim selulase Basilus subtitulis terhadap penurunan serat kasar kulit ubi kayu untuk bahan baku pakan ikan. Widyariset 2: 57-66.

Mithun S, Vijayagopal P, Chakraboty K, Chan DPS. 2018. Evaluation of gross protein and lipid requirements in formulated feed for honey gourami, Trichogaster chuna (Hamilton 1822). Journal of World Aquaculture Society 50: 800-814.

Mukti RC, Yonarta D, Pangawikan AD. The use of Indigofera zollingeriana leaves as feed ingredient of patin Pangasius sp.. Depik Jurnal Ilmu-Ilmu Perairan, Pesisir dan Perikanan 8: $18-25$

[NRC] National Research Council. 1993. Nutrient Requirement of fish. Washington DC. USA: National Academy Press.

Nurliana. Anna F. Sugito. Al azhar. 2019. Effect of soya wastes probiotic and palm kernel addition fermented by Aspergillus niger to the cellulase activity in broilers digestive tract. Jurnal Medika Veterinaria 13: 47-54.

Olude O. George F. Alegbeleye W. 2016. Utilization of autoclaved and fermented sesame Sesamum indicum L. seed meal in diets for Til-aqua natural male tilapia. Animal Nutrition 2: 339-344.

Palupi R, Abdullah L, Astuti DA, Sumiati. 2014. Potential and utilization of Indigofera sp. shoot leaf meal as soybean meal substitution in laying hen diets. Jurnal Ilmu Ternak dan Veteriner 19: 210-219.

Pamungkas. W. 2012. Apparent digestibility coefficient of crude fiber fraction on palm kernel meal that hydrolized by sheep rumen liquor enzyme for catfish Pangasius hypophthalmus diet. Jurnal Riset Akuakultur 7: 437-445.

Pandey G. 2013. Feed formulation and feeding technology for fishes. International Research Journal of Pharmacy 4: 23-30.

Pangentasari D. 2018. Composition and digestibility values of Indigofera zollingeriana leaf meal on seed Leptobarbus hoevenii which fermented with sheep rumen liquor. Jurnal Ikhtiologi Indonesia 18: 165-173.

Rahman MM, Han HS, Kang WK, Kim KD, Lee BJ, Lee SM. 2016. Apparent digestibility coefficients of the extruded pellet diets containing various fish meals for olive flounder, Paralichthys olivaceus. Fisheries and Aquatic Sciences 19: 27

Raveendran S, Parameswaran B, Ummalyma SB, Abraham A, Mathew AK, Madhavan A, Rebello S, Pandey A. 2018. Applications of Microbial Enzymes in Food Industry. Food Technology \& Biotechnology 56: 16-30.

Samtiya M, Aluko RE, Dhewa T. 2020. Plant food anti-nutritional factors and their reduction strategies: an overview. Food Production, Processing and Nutrition 2: 6

Santos WM, Costa LS, López-Olmeda JF, Costa NCS, Santos FAC, Oliveira CG, Guilherme HO, Bahiense RN, Luz RK, Ribeiro PAP. 2020. Dietary protein modulates digestive enzyme activities and gene expression in red tilapia juveniles. Animal 14: 1802-1810.

Suprayudi MA, Dimahesa W, Jusadi D, Setiawati M, Ekasari J. 2011. Liquid rumen crude enzyme supplementation in the plant protein based diet on growth performance of Nile tilapia Oreochromis niloticus. Jurnal Iktiologi Indonesia 11: 177-183. 
Sun Y, Zhao X, Liu H, Yang Z. 2019. Effect of fiber content in practical diet on feed utilization and antioxidant capacity of loach, Misgurnus anguillicaudatus. Journal of Aquaculture Research \& Development 10: 577.

Takeuchi T. 1988. Laboratory work-chemical evaluation of dietary nutrient. In Watanabe. $\mathrm{T}$ (ed). Fish nutrition and mariculture. Departemen of Aquatic Bioscience. Tokyo University of Fisheries. 179-233pp.

Van Soest PJ. 1976. New Chemical Methods for Analysis of Forages for The Purpose of Predicting Nutritive Value. Pref IX Internasional Grassland Cong.
Vinasyiam A, Suprayudi MA, Alimuddin. 2016. Digestive enzymes activities in Oreochromis niloticus fed diet supplemented with recombinant growth hormone. Jurnal Akuakultur Indonesia 15: 15-23.

Watanabe T. 1988. Fish nutrition and mariculture. Tokyo (JP) : Departement of Aquatic Bioscience. Tokyo University of Fisheries. JICA.

Zuraida. Jusadi D. Utomo NBP. 2012. The evaluation of utilization of sheep rumen liquor enzyme for hydrolisis of crude fiber content in coconut meal basic material fish diet. Jurnal Akuakultur Rawa Indonesia 1: 117-126. 